\title{
No longer the upstart
}

\section{The US biotechnology industry's lobby shop is at last making its mark. Its incoming president may have taken some flak for quitting Congress but, as Meredith Wadman discovers, he's relishing the change.}

Tommy Thompson. His top health-policy adviser, Amit Sachdev, was deputy commissioner for policy at the Food and Drug Administration. "We now have, I think, the strongest health-advocacy team of any healthcare institution in Washington, Greenwood told the Association of Bioscience Financial Officers this month.

At least one of his listeners was impressed. "I like the fact that he came from Congress," says William Baird, chief financial officer at PTC Therapeutics in South Plainfield, New Jersey. "He'll have a level of 2 access that a former staffer or lobbyist will not. After all, these are his former peers."

But some critics accuse BIO of raising false hope of cures for deadly diseases, endangering the planet with genetically modified foods, and producing costly medicines beyond many peoples' reach.

"They've tried to paint themselves as a voice of innovation, a voice of science, a voice of progress. And they've spent a fortune to shield themselves from the very deep concerns that many people have about the real-world practices of the companies behind $\mathrm{BIO}$, Insid er job: Jim Greenwood sees 'mind-boggling' potential in biotechnology. says Brian Tokar of the Instisays Sheldon Krimsky, a bioethicist and longtime industry observer at Tufts University in Medford, Massachusetts.

"It's a big operation. They have a major presence everywhere," agrees Tony Mazzaschi, an official at the Association of American Medical Colleges in Washington. "In many ways, I think BIO has eclipsed Pharma, he adds, referring to the trade group for the US drug industry.

Jim Greenwood, the former US congressman who in January became BIO's second president, says he is relishing his new position as salesman-in-chief for the industry. ${ }^{\alpha}$ The critical thing is to get people to understand the enormous potential here, he says. "It's mindboggling, what we're going to be able to do."

Greenwood succeeds Carl Feldbaum, a former prosecutor in the Watergate scandal and Pentagon inspector-general. The everaccessible Feldbaum oversaw the group's growth from a \$3.8-million operation with 18 staff to today's $\$ 45$-million, 104-person lobby shop with offices a ten-minute walk from the White House.

By Washington standards, BIO is still a midsized lobbying organization. But it is growing, gaining 225 members in the past year. As well as the small firms that make up most of its membership, BIO represents 15 major drug companies, including Pfizer, Merck, Novartis and AstraZeneca, all of which have partnerships with, or stakes in, biotechnology firms. It also contains large agribusiness corporations such as Monsanto, Dow and DuPont.

\section{Fresh direction}

When Greenwood was hired last year, he had been leading a congressional investigation into conflict-of-interest policies at the National Institutes of Health, and was just preparing to grill drug-makers on their failure to divulge negative clinical-trial results. He stood down from chairing the hearing, on the grounds that several of the companies being called to testify were BIO members.

His sudden transformation from congressional watchdog to business lobbyist drew some criticism (see Nature 430, 495; 2004). But Greenwood says it was a natural progression from his interest in health care. BIO is getting good value from his $\$ 800,000$ salary, he says: "It's not a leap up from my predecessor."

Greenwood has made an early mark by hiring other seasoned Washington players. His chief operating officer is Scott Whitaker, former chief-of-staff to then health secretary tute for Social Ecology in Plainfield, Vermont, of street demonstrations in Philadelphia.

Others less critical of the industry still say it should do more to temper expectations. "I see a lot of the companies still on overdrive with hype," says Arthur Caplan, a bioethicist at the University of Pennsylvania in Philadelphia. "If you read all the press releases, you'd presume that what you ought to do is prepare for immortality."

Yet it is clear that, despite a slow start to 2005 , investors are backing the industry. According to an Ernst \& Young report released this month, the revenues of US biotechnology companies grew by $17 \%$ from 2003 to 2004 .

And back in Washington, what was arguably BIO's finest hour is feeding a sense of optimism. Last month, when the House of Representatives voted to loosen restraints on federal funding for human embryonic stemcell research, several Republicans opposed to abortion voted for the bill.

${ }^{\alpha}$ That's a very historically important moment," says Greenwood. "It means we can wrestle this issue away from the abortion issue and make it about hope and human health. It's the beginning of the beginning." 